\title{
Impact of internship programs on professional and personal development of business students: a case study from Pakistan
}

\author{
Sadia Anjum *i]
}

\begin{abstract}
This study aims to evaluate the impact of internship programs on the professional as well as on personal development and skills of business students in Pakistan. The data of the study consisted of 800 undergraduating business students of 4-year degree programs from 15 universities of Pakistan. The study used structured questionnaire (35 close-ended questions assessed using 5-point Likert scale) comprised of six parts: Part l: Demographic information, Part II: Reasons for participation in internship, and Part III to VI: Assessment of information related to professional and personal growth and skills. The study employed descriptive analysis to evaluate demographic information and central tendencies of the responses. Furthermore, scale measurement analysis is used to check distribution normality of study data and reliability of the questionnaire. The results of the study depict the impact of internship programs on the professional and personal growth and skills of the business students of Pakistan.
\end{abstract}

Keywords: Internship programs, Business students, Professional development, Personal growth, Pakistan

\section{Introduction}

The change of life stages from a student to a professional is not always very simple. Students have to face many challenges when they enter into professional life. They have to adjust themselves according to the professional environment by implementing their conceptual knowledge in the new world of work. Usually, business students use their skills and theoretical business knowledge in their first jobs [2, 44]. By integrating conceptual knowledge and training through academic internship programs, students can be facilitated to better implement their concepts at the workplace [62]. According to Gault et al. [23], academic internships are a bridge to link the theory and practice by taking part in supervised and scheduled work. These internship programs not only improve students personal skills but also polish their

\footnotetext{
${ }^{*}$ Correspondence: sadiaanjum88@gmail.com

Department of Commerce and Finance, Government College University,

House\# 90, Gillani Street\# 4, Sadaqat Park Sanda Khurd, Lahore 54000,
}

Pakistan professional growth and experience. Today, educational institutes, students and business recruiters are well aware of the importance of internship programs $[28,1,11,30$, 40]. Internship programs are the opportunities for educational institutes to upgrade the students enrollment and prepare their curriculum $[9,18,32]$. For students, internships are experience of practical work [50]. As companies prefer those business graduates who have required skills and practical knowledge [42], internships supply valuable employees and competent job applicants to the companies [15]. Internship programs enable students to get training during their course programs and save companies' supervision and training costs by providing them trained employees [31].

Now the questions that come into the minds regarding internships are: Why internships are important? and Why business students do internships? The answer to every question related to internship programs is that they are short-term workplace practical experience which provide opportunities to the students to enter the job market during and after their undergraduation course 
programs [47]. Internships are excellent source of practical experience $[19,20,22,33,51]$, learning team work [53], for polishing resumes [63], for building personal and professional relationships and for earning real money [16]. Oehlert et al. [49] stated that more attention should be paid on the internship programs to meet the needs of growing competitive job market. But what is the exact value of an internship program for business students, educational institutes and employers? Unfortunately, to answer this question not much quantitative or qualitative literature work is available.

We are living in the earlier stage of twenty-first century in a global world. In under developing countries like Pakistan, education system is still in improvement process. Here, although teachers are facilitated, they are not directed to enhance practical knowledge of their students with conceptual knowledge during a course program. Inappropriate teaching methodology may be one of the reasons due to which students find it difficult to implement conceptual knowledge in solving their daily lives problems. This problem can be solved with the help of internship programs. In Pakistan, it is supposed the internship programs would be beneficial and helpful to improve the performance of the faculty members and to enhance the workplace experience of the students during the course work of their degrees.

\section{Purpose and objectives of the study}

The main purpose of this study is to determine how much internship programs are beneficial for the undergraduating business students for their future career development, professional and personal growth. This study also aims to evaluate the impact of internship programs on the improvement of the professional and personal skills of business students of Pakistan after the completion of their internship period. The following objectives are set by the study in order to reach and achieve the purpose of the study:

- To determine the background and rationale of engagement of business students in internship programs.

- To determine the impact of internship programs on professional as well as personal growth and skills of the undergraduating business students.

- To identify the strengths and weaknesses of internship programs existing in Pakistan.

\section{Need and importance of the study}

A large number of educational institutes are coming to the opinion that internship programs are an excellent source for career and professional preparation of the students. They provide work-related experience to the students. On the other hand, they make it easy for the companies to select flexible, experienced and highly qualified job applicants. So internship programs are rewarding to the students, educational institutes and employers [29, 52, 59]. This is the era of innovations and technological development and expansion. So it is necessary to grow such capabilities in the students that will assist them to deal with the modern world of work [25]. For this, there is a need to reform the educational system of Pakistan by improving teaching methods, curriculum development, involving more research and providing practical training to the students. Internship programs create a link between classroom concepts and real workplace experience. Students are the future of any country. It is the requirement of the time that if Pakistan wants to be a developed country, it should focus more on the practical training of the business students so that they can outperform in the real world of progress.

This detailed examination of internship programs is the prior research within Pakistan to evaluate the impact of internship on career preparation of the business students as well as on their professional and personal growth. This study is important because it supplies valuable recommendations to the companies, educational institutes and students regarding the advancement of internship programs to improve personal skills, professional growth, leadership skills and work-related experience of the Pakistani students.

\section{Theoretical framework}

This section deals with the explanation of the theoretical framework, review of the prior literature and conceptual framework of the study.

Social learning theory is related to this study priorly developed by Bandura [4] and extended by Lave and Wenger [39]. Social learning theory is a cognitive process that is set on the notion of changes in beliefs, concepts and knowledge and improves professional and personal learning process through participation in real work environment. The motive of the present study is to evaluate the impact of internship programs on the professional and personal growth of the business students of Pakistan.

\section{Review of the literature}

Work-related learning and practical training in the form of internship programs are vital for business students for their personal and professional development and to build their strong connections with the leading business organizations. However, most of the research works until recently have focused on the advancement of students knowledge and advantages of an internship program after its completion [57]. There is limited amount of research 
work on how internship programs assist in professional and personal growth and skills of business students especially in underdeveloped countries like Pakistan. Much attention is paid on knowledge of facts in formal educational classes. If a student works hard, pays attention in class and learns the classroom material by heart, he will definitely pass the examinations [3]. In formal classes, the major focus is on what students know, but in an internship program, the major focus is on what students do. Ronnestad and Skovholts ([53], pp. 20-22) stated that practicality of knowledge depends upon what students already know and how they associate their information with the situations they face in the real world of the work. Raskin ([51], p. 18) indicated through an empirical research that there is a huge gap between the linkage of classroom knowledge and practical work. Students and academic faculty members pay very little attention on gaining full benefit from internship opportunities. Sometimes, students just observe the internship work environment without applying their classroom knowledge to the situations they encounter there, and sometimes, educational advisors or faculty members do not properly guide their students to get full advantage from the internship opportunities [21]. Harrison and Kennedy [27] believed that an internship program can be made successful for students through proper recognition of internship plans and relevant industry participants, picking out motivational student interns, internship program evaluation, monitoring and feedback. They also identified that educational institutes and academic advisors should play a vital role in the implementation of an internship program.

Many previous studies have proved that internship programs improve the academic and professional performance of the business students who follow an internship program during or after the completion of their institutional degree $[17,36,58]$. Internship programs provide the opportunity to the business students to gain fruitful experience by implementing their classroom concepts in the real work settings $[8,26,45]$. Internship experience then has an impact on the professional growth and success of business students and helps them to receive good financial earnings in their first job [13, 24, 37]. Students also learn required skills acquired for their professional success $[6,38]$. Moreover, internship helps business students to develop good personal qualities and working habits as well as appreciable confidence level $[1,24,41$, $55,60]$. Internship opportunities make the students able to receive high-quality job offers sooner [38, 43, 54]. They help them to directly interact with corporate professionals and thus build a strong network for their first job [24, 56]. But different studies have shown that to achieve all the above-mentioned advantages related to internship, appropriate feedback is needed from both the corporate supervisor and the institutional supervisor of the student. As feedback is considered as a vital element in upgrading and maintaining the performance, quality of internship programs and professional learning of the business students, a proper feedback should be provided by company and academic supervisor to check the intern's progress $[12,34,46]$.

Corporates usually favor the job applicants with work experience and practical knowledge. Therefore, they sometimes have an eye on their interns to select them as their future employees [5, 7, 14, 24, 43]. In this way, companies also save their hiring and training costs [5]. Interns provide part-time help and innovative ideas and exchange other knowledge with the business firms [5, $61,64]$. On the other hand, the major disadvantages of internships for the organizations are that they have to provide guidance, extensive support, training and feedback to the interns at every stage in order to make them productive for the organizations [10].

Furthermore, internship programs help educational institutions to get reputation by strengthening their bonds with business world, availability of research grants, receive positive feedback from corporates on their curriculum and increase job opportunities for their students $[5,14,24,42,43,64]$. Although the existing literature provides a good overview of the benefits of internship programs for the business students, there is a lack of such empirical research in the context of underdeveloped countries like Pakistan. This study will give the overview of internship pros to the business students of Pakistan.

\section{Hypotheses}

The hypotheses of the study are as follows:

$\mathbf{H}_{\mathbf{1}}$ Internship programs have an impact on the professional development of the business students.

$\mathbf{H}_{2}$ Internship programs have an impact on the professional skills of the business students.

$\mathbf{H}_{3}$ Internship programs have an impact on the personal growth of the business students.

$\mathbf{H}_{4}$ Internship programs have an impact on the personal capabilities of the business students.

\section{Methods}

This section of the study elaborates methods of data collection, population and sampling procedures, analysis of data and the research design. This study was submitted to 
and approved by Advanced Studies and Research Committee of Government College University.

\section{Collection of data}

The study collected primary data from the final year business students of 4-year degree programs who did internships of 2-4 months from 15 prestigious educational institutes of Karachi, Lahore and Islamabad, namely Pakistan Institute of Development Economics, Islamabad; Bahria University, Islamabad, National University of Modern Languages, Islamabad; Air University, Islamabad; Quaid-i-Azam University, Islamabad; University of Engineering and Technology, Lahore; UCP, Lahore; COMSAT, Lahore; Punjab University, Lahore; Lahore University of Management Sciences; Iqra University, Karachi; Karachi Institute of Economics and Technology; Aga Khan University, Karachi; Institute of Business Management, Karachi; and Hamdard University, Karachi. "Appendix A" further shows percentage and frequency analysis of these universities. The data were collected in May and June 2019. In total, 800 questionnaires were distributed comprising of Part I: Demographic information, Part II: Reasons for participation in internship, Part III-Part VI: Assessment of information regarding professional and personal growth and skills improvement with 35 close-ended questions. The questionnaires were distributed and collected both physically and electronically. "Appendix B" shows sample of questionnaire.

\section{Population and sampling procedures}

The fourth-year business students of Pakistani universities were considered as the population of the study. As a large number of students pass out (90,682 business students as per current report of Higher Education Commission of Pakistan), sample of the study consisted of 800 business students from 15 Pakistani universities.

\section{Methodology}

This study is a quantitative research, but in order to better comprehend strengths and weaknesses of internship programs in Pakistan, some qualitative research elements were also utilized. The study employed both descriptive and statistical analyses to evaluate the impact of internship programs on the professional and personal growth and skills of Pakistani business students. Descriptive technique of the study consisted of percentage and frequency analysis of demographic characteristics of the participants and central tendency measurement of their responses, whereas statistical technique comprised of scale analysis including normality and reliability tests. Reliability of the questionnaire was tested using Cronbach's alpha, and normality was evaluated employing univariate and multivariate normality of skewness and kurtosis. Structured questionnaire technique was used, comprising of six parts, i.e., Part I: Demographic information, Part II: Reasons for participation in internship, Part III-Part VI: Assessment of information regarding professional and personal growth and skills improvement with 35 close-ended questions. Each variable of the questionnaire was assessed using 5-point Likert scale, where 1 is strongly disagree, 2 is disagree, 3 is neutral, 4 is agree and 5 is strongly agree.

\section{Results}

This section consists of empirical findings and their estimations. This section is divided into two parts, i.e., descriptive analysis and scale analysis.

\section{Descriptive analysis}

This section highlights the demographic characteristics of the respondents and central tendency measurement of their responses.

\section{Demographic characteristics}

This section of the study elaborates the findings of two parts of the questionnaire, i.e., demographic information and reasons for participation in an internship program. Tables 1 and 2 indicate the findings.

The results show that among 800 respondents, 744 (93\%) were 26 or less years of age and $56(7 \%)$ were in between 27 and 30 years of age. $396(49.5 \%)$ were males and $404(50.5 \%)$ were females. $180(22.5 \%)$ were students of accounting and finance program, 244 (30.5\%) were from BBA (Hons) degree, 99 (12.4\%) were from accounting (Hons) degree, and 277 (34.6\%) were B.Com (Hons) students. 177 (22.1\%) were working as an intern in finance departments, 189 (23.6\%) in marketing departments, $80(10 \%)$ in human resource departments, 144 $(18 \%)$ in product departments, $190(23.8 \%)$ in customer relationship departments, and $20(2.5 \%)$ in other departments of different business organizations. 492 (61.5\%) interns participated in an internship program for 6 or less weeks, 298 (37.3\%) worked for 7-16 weeks, and 10 (1.2\%) worked for 17-25 weeks.

These results depict that $10(1.2 \%)$ respondents did internship in spring semester, 759 (94.9\%) did in summer, $9(1.1 \%)$ participated in an internship program in fall semester, $12(1.5 \%)$ worked as an intern in spring/summer semester, and 10 (1.2\%) did internship in summer/ fall semester. $710(88.7 \%)$ were interested to work in the field of business, and 90 (11.3\%) were not interested at all in business field before their internship. 190 (23.7\%) respondents participated in an internship program as it was a departmental course requirement, 44 (5.5\%) did internship because advisor recommended it as an elective course, and 566 (70.8\%) participated in an internship 


\begin{tabular}{|c|c|c|}
\hline Item & Frequency & Percentage (\%) \\
\hline \multicolumn{3}{|l|}{ Age (years) } \\
\hline 26 or less & 744 & 93 \\
\hline $27-30$ & 56 & 7 \\
\hline \multicolumn{3}{|l|}{ Gender } \\
\hline Male & 396 & 49.5 \\
\hline Female & 404 & 50.5 \\
\hline \multicolumn{3}{|l|}{ Degree (4 years) } \\
\hline BS-Accounting and Finance & 180 & 22.5 \\
\hline BBA (Hons) & 244 & 30.5 \\
\hline BS-Accounting (Hons) & 99 & 12.4 \\
\hline B.Com (Hons) & 277 & 34.6 \\
\hline \multicolumn{3}{|l|}{ Job title at internship } \\
\hline Finance Assistant & 177 & 22.1 \\
\hline Marketing Assistant & 189 & 23.6 \\
\hline Human Resource Department Assistant & 80 & 10 \\
\hline Product Department Assistant & 144 & 18 \\
\hline $\begin{array}{l}\text { Customer Relation Department } \\
\text { Assistant }\end{array}$ & 190 & 23.8 \\
\hline Others & 20 & 2.5 \\
\hline \multicolumn{3}{|l|}{ Length of internship (weeks) } \\
\hline 6 or less & 492 & 61.5 \\
\hline $7-16$ & 298 & 37.3 \\
\hline $17-25$ & 10 & 1.2 \\
\hline
\end{tabular}

to gain practical experience. $177(22.1 \%)$ considered that internship is important to complete academic credit, $289(36.1 \%)$ thought that an internship is important as it links classroom concepts with real work environment, 258 (32.3\%) believed that it provides direction toward independent life, and 76 (9.5\%) considered its importance for purposes other than stated above. 639 (79.9\%) participants agreed that their internships helped them in obtaining their current jobs, whereas 161 (20.1\%) lacked this belief. 569 (71.1\%) agreed that internship programs influence the future job promotion, whereas 231 (28.9\%) did not agree. 610 (76.2\%) received incentives from companies while being in internship, while 190 (23.7\%) did not receive such incentives. 455 (56.9\%) received award while being in internship, while 345 (43.1\%) did not receive any award.

\section{Measurement of central tendencies}

This part deals with the findings of mean and standard deviation for the items of Part III to Part VI of the questionnaire. Table 3 shows the results.
These results show central tendencies of the responses for all the items of Part III to Part VI of the questionnaire by 800 participants of the study. The highest mean and highest standard deviation (SD) for professional development (PD) are 3.3451 and 0.3217 , respectively. The lowest mean and lowest SD for PD are 2.9261 and 0.0235 , respectively. The range of mean 2.9261-3.3451 depicts that responses of business students are moving from "disagree" to "agree" for all the items of PD. The lowest and highest means for professional skills (PS) are 3.7129 and 4.3127, while the lowest SD and highest SD are 0.0217 and 0.6133 , respectively. The mean range 3.7129-4.3127 shows positive responses of business students for all the items of PS. The lowest mean and lowest SD for personal growth (PG) are 4.1209 and 0.4259 , whereas the highest mean and highest SD are 4.5129 and 0.7521 , respectively. The mean range 4.1209-4.5129 indicates that business students "agreed" with all the items of PG. The lowest and highest means for personal capabilities (PC) are 3.7121 and 4.6713, the while lowest SD and highest SD are 0.2960 and 0.7511 , respectively. The mean range 3.7121-4.6713 shows positive responses of business students for all the items of PC.

\section{Scale measurement}

This section elaborates normality and reliability tests results, evaluated to check the normality of distribution of the data of the study and reliability of the questionnaire.

\section{Multivariate normality test}

The acceptable skewness range is \pm 3 with acceptable kurtosis range of \pm 10 [35]. The data of the study will be normally distributed if values of kurtosis and skewness fall within this range. Table 4 shows the results.

These results show that critical values of kurtosis range from - 1.6231 (PD6) to 1.6337 (PS6), whereas critical values of skewness range from -0.7176 (PG5) to 0.7621 (PC5). The results indicate that all the values of kurtosis and skewness fall in the acceptable range; therefore, the data of the study are normally distributed.

\section{Reliability test}

The reliability of the questionnaire is checked using Cronbach's coefficient alpha. Nunnally and Bernstein [48] described that if Cronbach's coefficient alpha is above 0.70 , then questionnaire becomes reliable. Table 5 shows the results.

The results represent that values of Cronbach's coefficient alpha range from 0.7113 to 0.8239 . As critical values fall in acceptable range, the questionnaire of the study is reliable. 
Table 2 Percentage and frequency distribution of reasons for participation in internship Source: developed for the study

\begin{tabular}{|c|c|c|}
\hline Item & Frequency & Percentage (\%) \\
\hline \multicolumn{3}{|l|}{ When did perform internship? } \\
\hline Spring & 10 & 1.2 \\
\hline Summer & 759 & 94.9 \\
\hline Fall & 9 & 1.1 \\
\hline Spring/summer & 12 & 1.5 \\
\hline Summer/fall & 10 & 1.2 \\
\hline \multicolumn{3}{|c|}{ Interest of working in accounting/finance business before internship participation } \\
\hline Yes & 710 & 88.7 \\
\hline No & 90 & 11.3 \\
\hline \multicolumn{3}{|l|}{ Reasons for participation in internship program } \\
\hline Department course requirement & 190 & 23.7 \\
\hline Advisor recommended elective course & 44 & 5.5 \\
\hline Own decision to gain practical experience & 566 & 70.8 \\
\hline Others & 0 & 0 \\
\hline \multicolumn{3}{|l|}{ Expectations from internship } \\
\hline Academic credit & 177 & 22.1 \\
\hline Link classroom learning to workplace reality & 289 & 36.1 \\
\hline Direction for better participation for independent life & 258 & 32.3 \\
\hline Others & 76 & 9.5 \\
\hline \multicolumn{3}{|l|}{ Current and future employment } \\
\hline \multicolumn{3}{|l|}{ Influence on obtaining current job } \\
\hline Yes & 639 & 79.9 \\
\hline No & 161 & 20.1 \\
\hline \multicolumn{3}{|l|}{ Influence upon future job promotions } \\
\hline Yes & 569 & 71.1 \\
\hline No & 231 & 28.9 \\
\hline \multicolumn{3}{|l|}{ Company awards } \\
\hline \multicolumn{3}{|l|}{ Important incentives to interns } \\
\hline Yes & 610 & 76.2 \\
\hline No & 190 & 23.7 \\
\hline \multicolumn{3}{|l|}{ Received awards while being in internship? } \\
\hline Yes & 455 & 56.9 \\
\hline No & 345 & 43.1 \\
\hline
\end{tabular}

\section{Discussion}

Strengths and weaknesses of internship programs in Pakistan

Comments of the business respondents suggest the following key points about the strengths of the internship programs in Pakistan: (1) Almost all business schools are focusing to encourage their students to gain practical experience through internships; (2) viva voce of students is conducted after the completion of their internship period in order to evaluate their practical experience; (3) government of Pakistan is offering different internship programs at provincial level to fill the vacant job positions with right job applicants; and (4) as companies prefer their interns as their future employees, this encourages students to participate in internship programs.

The following weaknesses are suggested by the comments of the respondents: (1) There is a lack of coordination between company and academic supervisors; (2) only selected assignments are given to the students by the companies with not much encouraging environment to ask what students want; and (3) proper feedback is not provided by the firms to their interns and their academic supervisors.

\section{Policy implications}

Internship programs link classroom knowledge with the workplace realities and provide an experimental 
Table 3 Measurement of central tendencies Source: developed for the study

\begin{tabular}{|c|c|c|c|}
\hline Variables & Items & Mean & $\begin{array}{l}\text { Standard } \\
\text { deviation } \\
\text { (SD) }\end{array}$ \\
\hline \multirow[t]{6}{*}{ Professional development (PD) } & PD1 & 2.9427 & 0.3217 \\
\hline & PD2 & 3.1087 & 0.1605 \\
\hline & PD3 & 3.0052 & 0.0235 \\
\hline & PD4 & 3.2913 & 0.2761 \\
\hline & PD5 & 3.3451 & 0.1529 \\
\hline & PD6 & 2.9261 & 0.0343 \\
\hline \multirow[t]{6}{*}{ Professional skills (PS) } & PS1 & 3.7129 & 0.5672 \\
\hline & PS2 & 3.8200 & 0.0217 \\
\hline & PS3 & 4.3127 & 0.6133 \\
\hline & PS4 & 4.0299 & 0.1239 \\
\hline & PS5 & 4.1276 & 0.4321 \\
\hline & PS6 & 4.2396 & 0.5543 \\
\hline \multirow[t]{6}{*}{ Personal growth (PG) } & PG1 & 4.3217 & 0.4259 \\
\hline & $P G 2$ & 4.1209 & 0.6132 \\
\hline & PG3 & 4.3627 & 0.5929 \\
\hline & PG4 & 4.5129 & 0.7521 \\
\hline & PG5 & 4.2321 & 0.6222 \\
\hline & PG6 & 4.4291 & 0.5913 \\
\hline \multirow[t]{6}{*}{ Personal capabilities (PC) } & PC1 & 3.7121 & 0.4210 \\
\hline & PC2 & 3.9240 & 0.5921 \\
\hline & PC3 & 4.2917 & 0.7511 \\
\hline & PC4 & 4.0101 & 0.6920 \\
\hline & PC5 & 4.3352 & 0.3213 \\
\hline & PC6 & 4.6713 & 0.2960 \\
\hline
\end{tabular}

experience to the students and enable them to make their place in the dynamic job market of this modern era. The present study will help and encourage the business students of Pakistan to focus more on gaining experimental knowledge from real world of the work so that they can easily get their first job and future job promotions. It will also assist business schools to develop proper strategies and curriculum for the promotion of internship programs so that besides theoretical knowledge, practical knowledge can also be provided to the business students during the graduation. It will also help to the companies to offer effective internship programs, training and learning environment to their interns. In this way, they can reduce their recruitment and training costs to the new employees.

\section{Future recommendations}

Future research can be conducted gathering firms and business schools perceptions about the internship programs. Future studies can also be conducted by comparing internship programs of different countries.
Table 4 Skewness and kurtosis test Source: developed for the study

\begin{tabular}{llrr}
\hline Variables & Items & Kurtosis & Skewness \\
\hline Professional development (PD) & PD1 & 0.1729 & 0.7217 \\
& PD2 & 0.2391 & -0.5213 \\
& PD3 & -0.1655 & -0.0222 \\
& PD4 & 0.3617 & 0.0137 \\
& PD5 & 0.6239 & -0.1621 \\
& PD6 & -1.6231 & 0.5921 \\
Professional skills (PS) & PS1 & 1.2317 & 0.1329 \\
& PS2 & 0.5613 & -0.5236 \\
& PS3 & 0.3215 & -0.1772 \\
& PS4 & -1.2322 & -0.1995 \\
Personal growth (PG) & PS5 & -0.2923 & 0.2316 \\
& PS6 & 1.6337 & 0.3216 \\
& PG1 & 1.2359 & -0.3232 \\
& PG2 & 0.7263 & -0.1632 \\
& PG3 & 0.4161 & 0.5217 \\
& PG4 & -0.3269 & 0.4235 \\
PG5 & 0.5217 & -0.7176 \\
& PG6 & 0.3279 & 0.1329 \\
& PC1 & -1.6230 & -0.0366 \\
& PC2 & 0.0321 & 0.4267 \\
& PC3 & 0.4255 & -0.0217 \\
& PC4 & 0.5279 & 0.1629 \\
& PC5 & 0.7162 & 0.7621 \\
& PC6 & 0.4316 & 0.5316 \\
\hline & & &
\end{tabular}

Table 5 Reliability analysis Source: developed for the study

\begin{tabular}{lll}
\hline Variables & No. of items & Cronbach's alpha \\
\hline Professional development & 6 & 0.7129 \\
Professional skills & 6 & 0.7701 \\
Personal growth & 6 & 0.8239 \\
Personal capabilities & 6 & 0.7113 \\
\hline
\end{tabular}

\section{Conclusion}

The study aimed to evaluate the impact of internship programs on the professional and personal development and skills of the business students of Pakistan. The data of the study comprised of 800 undergraduating business students of 4-year degree programs from 15 Pakistani universities. The study got responses from the participants using structured questionnaire technique consisting of six parts, i.e., Part I: Demographic information; Part II: Reasons for participation in internship; Part III-Part VI: Assessment of information regarding professional and personal growth and skills improvement of the business 
students. Each item of the questionnaire (35 close-ended questions) was assessed using 5-point Likert scale. The study employed descriptive analysis to evaluate demographic information and measured central tendencies using mean and standard deviation to evaluate the nature of the responses of the participants. Furthermore, scale measurement analysis was made to check the normality of distribution of the study data and reliability of the questionnaire.

The results of central tendency measurement indicate "disagree to agree," "positive" and "agreed" responses of the participants for all the items of the questionnaire. Normality test results show that critical values of kurtosis range from -1.6231 to 1.6337 , whereas critical values of skewness range from -0.7176 to 0.7621 . As critical values of kurtosis and skewness fall within the acceptable range, the data of the study are normally distributed. Moreover, reliability test results using Cronbach's coefficient alpha indicate that all critical values of Cronbach's alpha exceed 0.70 , so the questionnaire of the study is reliable. The overall results depict that internship programs have an impact on the professional growth and skills of the business students of Pakistan, affecting their personal development, skills and capabilities. The results are consistent with English and Koeppen [17], Hall et al. [26], Gault et al. [24], Weible [64], McDonald et al. [42].

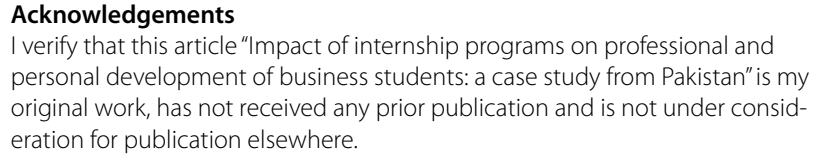

I verify that this article "Impact of internship programs on professional and personal development of business students: a case study from Pakistan" is my original work, has not received any prior publication and is not under consideration for publication elsewhere.

Authors' contributions

$\mathrm{SA}$ is the only author of the manuscript and the sole contributor.
Funding

This research did not receive any specific grant from funding agencies in the public, commercial or not-for-profit sectors.

\section{Availability of data and materials}

The data will be provided on request.

Competing interests

Not applicable.

\section{Appendix A}

Frequency and percentage of demographic characteristic: universities

\begin{tabular}{|c|c|c|}
\hline Variable (Universities) & Frequency & $\begin{array}{l}\text { Percentage } \\
\text { (\%) }\end{array}$ \\
\hline $\begin{array}{l}\text { Pakistan Institute of Development Econom- } \\
\text { ics, Islamabad }\end{array}$ & 70 & 8.7 \\
\hline Bahria University, Islamabad & 80 & 10 \\
\hline $\begin{array}{l}\text { National University of Modern Languages, } \\
\text { Islamabad }\end{array}$ & 50 & 6.2 \\
\hline Air University, Islamabad & 60 & 7.5 \\
\hline Quaid-i-Azam University, Islamabad & 80 & 10 \\
\hline $\begin{array}{l}\text { University of Engineering and Technology, } \\
\text { Lahore }\end{array}$ & 70 & 8.7 \\
\hline UCP, Lahore & 80 & 10 \\
\hline COMSAT, Lahore & 60 & 7.5 \\
\hline Punjab University, Lahore & 50 & 6.2 \\
\hline Lahore University of Management Sciences & 40 & 5 \\
\hline Iqra University, Karachi & 40 & 5 \\
\hline $\begin{array}{l}\text { Karachi Institute of Economics and Technol- } \\
\text { ogy }\end{array}$ & 30 & 3.7 \\
\hline Aga Khan University, Karachi & 30 & 3.7 \\
\hline Institute of Business Management, Karachi & 30 & 3.7 \\
\hline Hamdard University, Karachi & 30 & 3.7 \\
\hline
\end{tabular}

Source: developed for the study 


\section{Appendix B}

\section{Questionnaire}

\section{RESEARCH TITLE: Impact of Internship Programs on Professional and Personal Development of Business Students - A Case Study from Pakistan}

Dear respondent,

The purpose of this survey is to examine the impact of internship programs on professional and personal growth as well as on professional and personal skills improvement of under-graduating business students of Pakistan.

Your participation is highly appreciated. Thank you.

Instructions:

1. There are Six (6) parts in this questionnaire. Please answer ALL questions in ALL parts.

2. Completion of this questionnaire will take you approximately 5 to 10 minutes.

\section{Part I. About Yourself}

Please respond to the related questions in this section.

1. What degree do you have?

a) BS-Accounting and Finance (Hons)

b) BBA (Hons)

c) BS-Accounting (Hons)

d) B.Com (Hons)

2. What was your job title as an intern?

3. Length of internship experience means how many weeks of duration was your internship?

4. What is your age? (years)

5. What is your gender?

\section{Part II. Reasons for Participation in Internship}

1. Why did you decide to become involve in the internship program?
a) Department course requirement
b) Advisor recommended elective course
c) Own decision to gain practical experience
d) Others (Please explain) 
2. What did you expect to gain from internship? (Please circle all that apply)
a) Academic credit
b) Link classroom learning to workplace reality
c) Direction for better preparation for independent life
d) Others (Please explain)

3. Were you interested in working in accounting/ finance business before internship?
(Please Circle)
Yes.
No.

4. When did you perform your internships?

(Please check all that apply)
a) Spring
b) Summer
c) Spring/ Summer
d) Summer/ Fall
e) Fall

5. Impact on current and future job employment

a) Do you believe your internship experience will help you get your current job? (Please Circle). Yes. No.

b) Do you believe your internship experience will help you get future job promotion? (Please Circle). Yes. No.

6. While being with a company as an intern

a) Do you believe company awards are important incentives to interns? (Please Circle).

Yes. No.

b) Did you receive any company awards as an intern? (Please Circle).

Yes.

No. 


\section{Part III: professional development}

Please indicate your level of agreement with each of the following statements about internship impact. Please check the suitable response.

\begin{tabular}{|c|c|c|c|c|c|c|}
\hline Items & Questions & Strongly disagree & Disagree & Neutral & Agree & Strongly agree \\
\hline PD1 & My internship program changed me professionally & 1 & 2 & 3 & 4 & 5 \\
\hline PD2 & Internship program made clear my career goals & 1 & 2 & 3 & 4 & 5 \\
\hline PD3 & I have applied my classroom knowledge during my internship & 1 & 2 & 3 & 4 & 5 \\
\hline PD4 & $\begin{array}{l}\text { Internship helped me to gain practical work experience in my field } \\
\text { of interest }\end{array}$ & 1 & 2 & 3 & 4 & 5 \\
\hline PD5 & $\begin{array}{l}\text { Internship helped me to identify the skills needed to get a job in } \\
\text { my field of interest }\end{array}$ & 1 & 2 & 3 & 4 & 5 \\
\hline PD6 & $\begin{array}{l}\text { I faced some problems to seek and accept work assignments } \\
\text { during internship }\end{array}$ & 1 & 2 & 3 & 4 & 5 \\
\hline
\end{tabular}

\section{Part IV: professional skills}

Do you believe internship program contributed to your professional skills development? Please check the suitable response.

\begin{tabular}{|c|c|c|c|c|c|c|}
\hline Items & Questions & Strongly disagree & Disagree & Neutral & Agree & Strongly agree \\
\hline PS1 & $\begin{array}{l}\text { Internship improved my communication and interpersonal team } \\
\text { skills }\end{array}$ & 1 & 2 & 3 & 4 & 5 \\
\hline PS2 & It enhanced my decision making and problem solving skills & 1 & 2 & 3 & 4 & 5 \\
\hline PS3 & It improved my skills to work as a team & 1 & 2 & 3 & 4 & 5 \\
\hline PS4 & It enhanced my critical thinking & 1 & 2 & 3 & 4 & 5 \\
\hline PS5 & It improved my computer skills & 1 & 2 & 3 & 4 & 5 \\
\hline PS6 & $\begin{array}{l}\text { It improved my skills in technical field of accounting and finance } \\
\text { business }\end{array}$ & 1 & 2 & 3 & 4 & 5 \\
\hline
\end{tabular}

\section{Part V: personal growth}

Questions in this section deal with personal growth related to internship experiences. Please check the suitable response.

\begin{tabular}{|c|c|c|c|c|c|c|}
\hline Items & Questions & Strongly disagree & Disagree & Neutral & Agree & Strongly agree \\
\hline PG1 & $\begin{array}{l}\text { Internship program made me mature professionally and person- } \\
\text { ally }\end{array}$ & 1 & 2 & 3 & 4 & 5 \\
\hline PG2 & It changed my personal career goals & 1 & 2 & 3 & 4 & 5 \\
\hline PG3 & $\begin{array}{l}\text { It positively changed my interest in accounting and finance } \\
\text { related business }\end{array}$ & 1 & 2 & 3 & 4 & 5 \\
\hline PG4 & $\begin{array}{l}\text { I developed a habit to accomplish my task before the set target } \\
\text { after internship }\end{array}$ & 1 & 2 & 3 & 4 & 5 \\
\hline PG5 & My internship practically improved my classroom concepts & 1 & 2 & 3 & 4 & 5 \\
\hline PG6 & Internship changed my personal aspirations in some ways & 1 & 2 & 3 & 4 & 5 \\
\hline
\end{tabular}




\section{Part VI: personal capabilities}

Do you believe the following characteristics are positively influenced by internship program? Please check the suitable response.

\begin{tabular}{|c|c|c|c|c|c|c|}
\hline Items & Questions & Strongly disagree & Disagree & Neutral & Agree & Strongly agree \\
\hline PC1 & Internship improved my conscientiousness and ethics & 1 & 2 & 3 & 4 & 5 \\
\hline PC2 & $\begin{array}{l}\text { It polished my habit to have a respect for people different } \\
\text { from myself }\end{array}$ & 1 & 2 & 3 & 4 & 5 \\
\hline PC3 & It taught me how to learn & 1 & 2 & 3 & 4 & 5 \\
\hline PC4 & It improved my skills to manage my time and money & 1 & 2 & 3 & 4 & 5 \\
\hline PC5 & It improved my social relationships & 1 & 2 & 3 & 4 & 5 \\
\hline PC6 & It enhanced my initiative taking & 1 & 2 & 3 & 4 & 5 \\
\hline
\end{tabular}

\section{Thank You Very Much!!!}

Received: 9 August 2019 Accepted: 18 December 2019

Published: 10 January 2020

\section{References}

1. Arnold MJ, Cannon JA (1998) Student expectations of collegiate internship program in business: a 10-year update. J Educ Bus 73(4):202-205. https://doi.org/10.1080/08832329809601630

2. Arts JA, Gijselaers WH, Boshuizen H (2006) Understanding managerial problem-solving, knowledge use and information processing: investigating stages from school to the workplace. Contemp Educ Psychol 31(4):387-410

3. Baird BN (1999) The internship, practicum and field placement handbook, a guide for the helping professions. Prentice-Hall Inc., Upper Saddle River

4. Bandura A (1977) Social learning theory. Prentice Hall, New Jersey

5. Beard DF (1998) The status of internships/cooperative education experiences in accounting education. J Account Educ 16(3/4):507-516

6. Beard DF (2007) Assessment of internship experiences and accounting core competencies. Account Educ Int J 16(2):207-220. https://doi. org/10.1080/09639280701234625

7. Beckett H (2006) All good practice. People Manag 12(5):38-40

8. Beenen G, Mrousseau DM (2010) Getting the most from MBA internships: promoting intern learning and job acceptance. Hum Resour Manag 49(1):3. https://doi.org/10.1002/hrm.20331

9. Benton P (1990) The Oxford internship scheme: integration + partnership in initial teacher education. Galouste Gulbenkian Foundation, London

10. Birch C, Allen J, McDonald J, Tomaszczyk E (2010) Graduate internships: bridging the academic and vocational divide. In: Halley S, Birch C, Trmpelaar DT, McCuddy M, Hernandez Nanclares N, Reeb-Gruber S, Gijselaers WH, Rienties B, Nelissen E (eds) Proceedings of the 17th ENINEB conference: crossing borders in education and work-based learning. FEBA ERD Press, London, pp. 194-195

11. Bower AM (1989) Getting at the core of the New York State mentor teacher: internship program—relationships. lowa State University Library, Ames, IA. (ERIC document reproduction service, no. ED303463)

12. Brooks L, Cornelius A, Greenfield E, Joseph R (1995) The relation of careerrelated work or internship experience to the career development of college seniors. J Vocat Behav 46(3):332-349

13. Callanan G, Benzing C (2004) Assessing the role of internships in the career-oriented employment of graduating college students. Educ Train 46(2):82-89

14. Coco M (2000) Internships: a try before you buy agreement. Adv Manag J 65:41-47

15. Crumbley DL, Sumners GE (1998) How businesses profit from internships? Intern Audit 55(10):54-55

16. Dickey EB (1979) Faculty internships are "catching on" at South Carolina. Journal Educ 34(3):20-21
17. English DM, Koeppen DR (1993) The relationship of accounting internships and subsequent academic performance. Issues Account Educ 22:45-53

18. Eyler J (1993) Comparing the impact of two internship experiences on student learning. J Coop Educ 29(1):41-52

19. Farrell AM (1992) What teachers can learn from industry internships? Educ Leadersh 49(6):38-39

20. Fosdick JA (1979) Post-interns change views of the media, J-Education. Journal Educ 34(2):22-25

21. Frantzich S (1977) Storming Washington: an intern's guide to national government. American Political Science Association, Washington, D.C

22. Gary LD (1999) My summer intern experience at First Union Capital Markets Group. http://members.tripod.com/-Gary_Dove/weeklO.html

23. Gault J, Leach E, Duey M (2010) Effects of business internships on job marketability: the employers' perspective. Educ Train 52(1):76-88

24. Gault J, Redington J, Schlager T (2000) Undergraduate business internships and career success: are they related? J Mark Educ 22:45-53

25. Gerasimova IB (1998) Problems of training science-teaching cadres. Russ Educ Soc 40(8):91-95

26. Hall M, Stiles G, Kuzma J, Elliott K (1998) A comparison of student and employer expectations with regard to business internships. Mark Educ Rev 5(3):41-49

27. Harrison RW, Kennedy PL (1996) A framework for implementing agribusiness internship programs. Agribusiness 12(6):561-568

28. Hirst R (1996) The value of faculty internships in technical communication. J Tech Writ Commun 26(1):79-96

29. Hodgson P (1999) Making internships well worth the work. Techniques 74(6):38-39

30. Horowitz EM (1996) Chasing the pot of gold: internships on the road to employment. lowa State University Library, Ames, IA. (ERIC document reproduction service, no. ED401551)

31. Hurst JL, Good LK (2010) A 20-year evolution of internships: implications for retail interns, employers and educators. Int Rev Retail Distrib Consum Res 20(1):175-186. https://doi.org/10.1080/09593960903498342

32. Hymon-Parker S (1998) Benefits and limitations of internships as viewed by educators and retailers. J Fam Consum Sci 90(4):76-80

33. Inkster R (1994) Internships and reflective practice: informing the workplace, informing the academy. lowa State University Library, Ames, IA. (ERIC document reproduction service, no. ED 234781

34. Johari A, Bradshaw AC (2006) Project-based learning in an internship program: a qualitative study of related roles and their motivational attributes. Educ Technol Res Dev 56:329-359

35. Kline RB (1998) Principles and practice of structural equation modeling Guilford Press, New York

36. Knechel WR, Snowball D (1987) Accounting internships and subsequent academic performance: an empirical study. Account Rev 62(4):799-807

37. Knemeyer AM, Murphy PR (2002) Logistics internships: employer and student perspectives. Int J Phys Distrib Logist Manag 32(2):135-152 
38. Knouse $\mathrm{SB}$, Fontenot $\mathrm{G}$ (2008) Benefits of the business college internship: a research review. J Employ Couns 45(2):61-66

39. Lave J, Wenger E (1991) Situated learning: legitimate peripheral participation. Cambridge University Press, Cambridge

40. Mamun M (1998) Social forestry program in the Majalengka forest district, West Java, Indonesia: agro forestry systems and extension services. Unpublished dissertation, lowa State University, Ames, IA

41. McCollum JK, Schoening NC (2004) Case study of management internships: Eastern Europeans in America. Int J Public Adm 27(11-12):905-915. https://doi.org/10.1081/LPAD-200037359

42. McDonald J, Birch C, Hitchman A, Fox P, Lido C (2010) Developing graduates employability through internships: new evidence from a UK university. In: Halley S, Birch C, Tempelaar DT, McCuddy M, Hernandez Nanclares N, Reeb-Gruber S, Gijselaers WH, Rienties B, Nelissen E (eds) Proceedings of the 17th EDINEB conference: crossing borders in education and workbased learning. FEBA ERD Press, London, pp. 349-358

43. Mello JA (2006) Enhancing the international business curriculum through partnership with the United States department of commerce: the "e" award internship program. J Manag Educ 30(5):690-699

44. Mintzberg H (2004) Managers not MBAs: a hard look at the soft practice of managing and management development. Berrett-Koehler, San Francisco

45. Muhamad R, Yahya Y, Shahimi S, Mahzan N (2009) Undergraduate internship attachment in accounting: the intern's perspective. Int Educ Stud 2(4):49-55

46. Narayanan VK, Olk PM, Fukami CV (2010) Determinants of internship effectiveness: an exploratory model. Acad Manag Learn Educ 9(1):61-80

47. Niebauer W (1978) The great equalizer: job experience. Community Coll Journal 7(1):23-24

48. Nunnally JC, Bernstein IH (1994) Psychometric theory, 3rd edn. McGrawHill, New York

49. Oehlert ME, Sumerall S, Lopez SJ (1998) Internship selection in professional psychology. A comprehensive guide for students, faculty and training directors. Charles C. Thomas Publisher, Ltd., Springfield

50. Posey LO, Carlisle KE, Smellie DC (1998) An internship study case: how internships can benefit the student, the university and the organization. Train Dev J 42(2):59

51. Raskin MS (1994) The Delphi study in field instruction revisited: expert consensus on issues and research priorities. J Soc Work Educ 30:75-89

52. Razzano E (1999) Recommended: the internship support is essential. Engl J 89(1):30-32
53. Ronnestad MN, Skovholt TM (1993) Supervision of beginning and advanced graduate students of counseling and psychotherapy. J Couns Dev 71:396-405

54. Rothman M, Lampe M (2009) Business school internships: sources and resources. In: Paper presented at the proceedings of ASBBS 2009, Las Vegas, US

55. Sapp DA, Zhang Q (2009) Trends in industry supervisors' feedback on business communication internships. Bus Commun Q 72(3):274-288. https://doi.org/10.1177/1080569909336450

56. Schambach TP, Driks J (2002) Student perceptions of internship experiences. In: Paper presented at the 17th annual conferences of the International Academy for Information Management, Barcelona, Spain

57. Schambach TP, Kephart D (1999) Do I/S students value internship experiences? In: Paper presented at the proceeding of the 17th International Academy for Information Management, Barcelona, Spain

58. Siegel PH, Rigsby JT (1988) The relationship of accounting internships and subsequent professional performance. Issues Account Educ 3(2):423-433

59. Swift CO, Kent R (1999) Business school internships: legal concerns. J Educ Bus 75(1):23-26

60. Tylor MS (1988) Effects of college internships on individual participants. J Appl Psychol 73(3):393-401

61. Tovey J (2001) Building connections between industry and university: implementing an internship program at a regional university. Tech Commun Q 10(2):225-239

62. Tynjälä $P$ (2008) Perspectives into learning at the workplace. Educ Res Rev 3(2):130-154

63. Veenendall TL, Freeman AR (1983) Making an internship program successful: the necessary ingredients. lowa State University Library, Ames, IA. (ERIC document reproduction service, no. ED249542)

64. Weible R (2010) Are universities reaping the available benefits internship programs offer? J Educ Bus 85:59-63

\section{Publisher's Note}

Springer Nature remains neutral with regard to jurisdictional claims in published maps and institutional affiliations.

\section{Submit your manuscript to a SpringerOpen ${ }^{\odot}$ journal and benefit from:}

- Convenient online submission

- Rigorous peer review

- Open access: articles freely available online

- High visibility within the field

- Retaining the copyright to your article

Submit your next manuscript at $\boldsymbol{\nabla}$ springeropen.com 